\title{
When Does Race Matter? Exploring White Responses to Minority Congressional Candidates
}

\author{
Neil Visalvanich *广 \\ School of Government and International Affairs \\ Durham University \\ The Al-Qasimi Building, Elvet Hill Road \\ Durham DH1 3TU, United Kingdom \\ email: neil.visal@gmail.com
}

January 30, 2016

\begin{abstract}
How significant of a factor is race in minority candidate evaluation? I present theory of race and minority candidate evaluation which argues that candidate race acts as an informational heuristic that affects perceptions of a candidate's ideological leaning and competence but that this effect is dependent on contextual factors, including the racial group and candidate partisanship. Using the 2010 and 2012 Cooperative Congressional Elections Study, I provide an observational look at Latino and Asian candidates in addition to black candidates for the first time, as well as minority candidates of both partisan stripes. I examine voter perceptions about candidates that might drive their vote choice, namely ideological assessments and competence assessments. I find that white voters are less likely to support Latino and black Democrats because they are viewed as less competent and more ideologically extreme. I find that Asian candidates and minority Republicans are largely unaffected by these biases.
\end{abstract}

*Durham University, School of Government and International Affairs, neil • visal@gmail . com

${ }^{\dagger}$ I would like to thank Marisa Abrajano, Nicole Bonoff, Christopher Fariss, James Fowler, Zoltan Hajnal, Hans Hassell, Seth Hill, Gary Jacobson, Thad Kousser, Nazita Lajevardi, Taeku Lee, Brad LeVeck, Kelly Matush, Scott Meinke, Lindsay Nielson, Michael Rivera, Keith Schnakenberg, and David Searle as well as the anonymous referees for their many helpful comments and suggestions. 


\section{Introduction}

Past studies have attempted to gauge the effect of a candidate's race on his or her political prospects, but these studies have produced inconsistent findings and have been unable to determine the perceptual mechanisms that mediate the relationship between a candidate's race and vote choice. Some have found that persistent prejudices have a negative effect on minority candidates (Terkildsen, 1993; Sigelman et al., 1995; Kinder and Sanders, 1996). On the other hand, many observational studies of minority candidates have found that the negative effect of race is largely dependent on electoral and candidate context (Highton, 2004; Hajnal, 2001, 2007; Citrin, Green and Sears, 1990), and that under certain contexts, like incumbency and campaign messaging, race might cease to be a significant consideration in vote choice. I argue that what is missing from these studies is a theory that considers how racial perceptions and electoral context might mediate candidate evaluations, as well as comprehensive data that can test a theory that considers many of the contextual variables that might go into a voter's decision to vote for or against a minority candidate. I argue that whether a candidate's race matters is dependent on two factors: the race of the candidate, and the party label that candidate runs under. Using expansive new survey data, I am able to test this theory and provide a comprehensive look at different types of minority candidates in America.

In an increasingly diverse America, we must ask whether candidates belonging to different racial groups are assessed in different ways. This study extends the analysis on minority candidates to Latino and Asian candidates for the first time. I hypothesize that attitudes towards minority candidates will reflect an emerging racial hierarchy in American politics, with Asians at the top and blacks and Latinos at the bottom. I also hypothesize that racial bias against minority candidates will be rooted in political stereotypes that see blacks and Latinos as less competent and more ideologically extreme than whites, and that these biases will be diminished by a stereotype-disconfirming partisan label (in other words, a Republican party label).

The 2010 and 2012 Congressional elections featured an extremely diverse set of candidates, with black, Latino and Asian candidates running for office under both party banners. By combining the natural diversity of this candidate set with the 2010 and 2012 Cooperative Congressional Elections Study (CCES), I am able to explore the electoral nuances of race in a way that incorporates a number of vari- 
ables prior studies were unable to consider. The CCES is a nationally representative internet survey that asks respondents not just whom for they voted but also to rate the ideological leanings and assess the competence of their respective candidates. Using this data, not only am I able to uncover racial bias in the vote, I am also able to link bias in the vote to perceptual biases against minority candidates.

I find a strong perceptual bias against Latino and black Democratic candidates in both ideological evaluation and assessment of competence. I also find that these biases do not apply to Asian Democrats and black and Latino Republicans. In addition, I find that these perceptual biases account for the bias in the vote against black and Latino candidates. Finally, I find that these biases are especially prevalent among those with negative racial attitudes.

\section{Minority Candidates and Vote Choice}

While studies on the electoral campaigns of President Obama point to a strong racial effect in vote choice and candidate evaluation (Schaffner, 2011; Kinder and Dale-Riddle, 2012; Stephens-Davidowitz, 2013; Beck, Tien and Nadeau, 2010; Highton, 2011; Piston, 2010), studies about minority candidates at other levels of government have either not addressed the candidacies of Latinos or Asians or have yielded mixed results. Electoral data suggests that minorities, especially Asians and Latinos, remain underrepresented in elected office (Hajnal, 2010), and that there is disparity in the racial composition of electorates that elect minority candidates, with most black and Latino representatives coming from majority minority districts. Asians are the notable exception to this trend, as most Asian representatives are elected in majority white areas (Hajnal, 2007). The thrust of the literature has focused on black candidates, and several prominent studies have found that black candidates fare worse among white voters when paired against white candidates (Terkildsen, 1993; Reeves, 1997; Bullock and Dunn, 1999). These studies seek to isolate the effect of race experimentally, and find a significant racial penalty incurred by black candidates, not just in the vote, but also in evaluation of candidate quality and ideological extremity (Williams, 1990; Sigelman et al., 1995; McDermott, 1998). According to this narrative, overtly prejudicial attitudes may be a thing of the past, but a type of averse or "modern" racism in which whites evaluate their minority candidates negatively despite their qualifications, still exists.

On the other hand, several studies have found race to be a minor or insignificant impediment for 
minority candidates. Notable among these studies is Highton (2004), who examined real world black candidates using exit polls. He finds that black incumbents are evaluated on par with their white counterparts and are just as likely to be re-elected. His findings are echoed by Bullock (2000), who studies aggregate white turnout and finds that black Democrats do not receive a lower proportion of the white vote when compared to white Democrats, as well as Voss and Lublin (2001) who examine the 1996 Congressional elections and find that southern whites are not consistently biased against black candidates. These studies are supported by surveys of white voters that have found them to be increasingly less resistant to vote for minority candidates (Schuman, Steeh and Bobo, 1985; Jones, 2012). These results back a narrative of an increasing egalitarianism in American society. According to this narrative, America has changed to the point where race is no longer the predominant motivating factor in the issue positions and political behavior of whites, and that most of the opposition to minority candidates and racial policy stems from political conservatism as opposed to racial bias (Abramowitz, 1994; Sniderman and Carmines, 1999; Feldman and Huddy, 2005; Thernstrom and Thernstrom, 1999).

Finally, a third view of minority candidacies views racial effects as largely contextual, dependent on factors independent of race. Citrin, Green and Sears (1990) examine the California gubernatorial election between Tom Bradley (a black Democrat) and George Deukmejian (a white Republican) and find that the significance of race is based on contextual variables such as a candidate's prior record and campaign style. This study represents an important look at race as a contextual and sometimes conditional variable in the electoral decision-making of whites, but is ultimately limited by the scope of the data, which examines one gubernatorial race in one state. My study expands and contributes to this contextual view of race by incorporating new data and examining a wide array of minority candidates of both partisan political orientations to provide a more complete picture of the contextual effects of race on candidate evaluation.

I argue that the existing literature on race and candidate evaluation is missing two key components. First, it does not take into account the increasing racial and political diversity in American politics, and does not consider how the electorate might respond differently to candidates of different racial groups and partisan stripes. Second, prior observational studies are missing the full array of racial and non-racial variables necessary to create a test that measures the independent effect of race. I address both of these issues by utilizing a dataset that examines candidates from all the major racial groups in America: black, 
Latino, and Asian. I compare candidates of these groups to white candidates with similar characteristics by controlling for party, spending, incumbency, and candidate ideology by using candidate ideal point estimates. The data allows me to trace the origins of vote bias against minority candidates by examining how ideological and competence assessments of candidates drives white voting behavior. Finally, I examine the impact that differing racial attitudes have on minority candidate evaluation. To that end, I posit a contemporary theory of race and candidate evaluation that seeks to explain how race functions as a variable in the political attitudes of whites.

\section{A Theory of Race and Candidate Evaluation}

\subsection{When Does Race Matter?}

How does race figure into vote choice? Popkin (1994) forwards a theory of low-information rationality which argues that voters often make choices based on informational heuristics and cues, such as partisan affiliation and incumbency. Using this literature as a theoretical base, I propose a view of racial politics which considers race as an informational heuristic. Voters incorporate a candidate's race as a part of a larger equation of political decision making. A candidate's race can cue different aspects of that candidate's politics, whether it be ideology, integrity, or competence.

The strength of race as an informational cue depends on the context of that information. Studies of racial candidate cues have found two distinct types of political stereotyping. The first of these is ideological stereotyping. Prior studies find that black candidates are seen as more liberal and more supportive of minority rights than white candidates (McDermott, 1998; Williams, 1990; Sigelman et al., 1995). Ideological stereotyping is not surprising, given black America's strong and enduring allegiance to the Democratic Party (Dawson, 1994). The second, more insidious strand of racial-political stereotyping is "competence" stereotyping, in which whites view minorities as inherently less capable and more illsuited for political office. Sigelman et al. (1995) finds that blacks and Latinos are stereotyped as being unable to manage major policy issues. Hajnal (2007) finds that among black challengers, stereotypes about incompetence are especially pervasive, which leads to a voting backlash among whites.

Because white responses to minority candidates are rooted in these political stereotypes, I hypothesize 
that the manner in which these stereotypes will effect electoral outcomes will depend on certain contexts, which I define as "stereotype-confirming" or "stereotype-disconfirming" contexts. The psychological basis for these two contexts lies in an "assumed-characteristics" interpretation of candidate qualities, in which information about a particular person's characteristics or beliefs can either serve to confirm or override prior biases (Locksley et al., 1980). The strength of candidate partisanship has been found to override policy positions and candidate information that contradicts normally held partisan stereotypes (Rahn, 1993). I explore whether the strength of partisanship can disconfirm the racial-political stereotypes that are normally applied to minority candidates. Because the strength of party labels plays such a strong role in affirming voter attitudes (Rahn, 1993; Nicholson, 2011), I hypothesize that a Democratic partisan affiliation will feed into pre-existing racial-political stereotypes and that this will lead to a racial bias against minority Democratic candidates. This bias should manifest itself in respondents rating their minority Democrats as more ideologically extreme. On the other hand, I hypothesize that the strength of the Republican party label will disconfirm these stereotypes.

While the expectations for minority ideological evaluations can be clearly delineated by party, formulating how a partisanship affects competence assessments is slightly more difficult. Prior studies (Sigelman et al., 1995) have found that whites view black and Latino candidates as significantly less competent than whites, but that negative assessments of competence also cut across party labels. The mechanism by which a candidate's party may mediate assessments of competence is "expectancy violation," in which white voters evaluate minority Republicans more favorably because they very clearly deviate from expected stereotypes. If this is the case, then we should expect a bias against competence assessments of minority Democrats, but no significant effects for minority Republicans.

From this informational theory of race and candidate evaluation, I posit my first hypothesis:

- 1. Racial-Political Stereotyping Hypothesis: Whites will be perceptually biased against minority Democrats, rating them as more ideologically extreme and less competent than their white counterparts. These biases will have a direct effect on the vote for minority Democrats. These biases will not apply to minority Republicans. 


\subsection{Which Races Matter?}

Most scholarly works on minority candidates focus primarily on black candidates and their relation to white voters (Hajnal, 2007, 2001; Highton, 2004; Bullock, 2000; Terkildsen, 1993). However, the literature on minority candidacies has yet to account for the increasing racial diversity in the array of candidates running for office at all levels of government. From Asian-American governors Bobby Jindal (R-LA) and former Washington Governor Gary Locke (D-WA), to Senators Marco Rubio (R-FL) and Ted Cruz (R-TX), who are of Latin American descent, America has seen a marked increase in the number of Latinos and Asians seeking and winning elected office, even among white majority electorates. Previous studies of Asian and Latino candidates have focused on the effect of minority candidacies on minority voters. Masuoka (2006) and Baretto (2007) have found increased participation among Asians and Latinos when they are voting for co-ethnic candidates. Many of these studies are motivated by the fact that, especially among blacks and Latinos, most minority candidates have run in majority-minority districts. However, the number of minorities seeking electoral support in white plurality/majority districts has increased, and studying the effect of race on white voters has become increasingly relevant. Minority candidates from each major racial group have sought and won office in white majority electoral districts, from municipal offices to the federal level.

How being of Latino or Asian descent affects a candidate's electoral prospects among whites is still mostly a mystery, despite increased political participation from both of these groups (Hajnal and Lee, 2011; Abrajano and Alvarez, 2010). Both Hajnal (2007) and McDermott (1998) find that black candidates, challengers in particular, lead to political stereotyping among white voters. Jacobsmeier (2014) finds that whites are more likely to perceive black candidates for Congress as more ideologically liberal than white candidates with similar ideological orientations. Do these stereotypes still apply for candidates of other races? My study will seek to answer this as yet unexplored question.

Extensive studies have been done about the different political stereotypes that afflict each racial group. Bobo (2001) conducted survey research about racial stereotypes and established the existence of a racial hierarchy in the attitudes of white americans. Both blacks and Latinos are seen as "lazy," "violent," more welfare dependent, and Latinos are more likely to be identified with an illegal citizenship status. Asians, on the other hand, are seen as hardworking and industrious and are closer to whites with regards 
to civic and social superiority, according to Kim (1999). Abrajano and Alvarez (2010) find that blacks, Latinos, and whites identify with Asians as a racial group the least when compared to other racial groups. While the literature on racial-political stereotyping provide certain expectations for Latinos and black candidates, expectations for Asian candidates are more muddy. I hypothesize that the stereotype of Asians as the model minority will make whites more receptive to their political candidacies since the expectations of public office largely play into the positive stereotypes of Asians as industrious and hardworking. ${ }^{1}$

If race does indeed function as a political cue, then we should expect that minority candidates of different racial stripes should inspire different political responses from whites. I propose a theory of racial hierarchy that considers the different role taken by each of the major racial groups in contemporary America. Not all minority candidates will evoke the same reactions from white voters. Black candidacies, having roots in a more thoroughly established political history and clear racial political allegiance towards the Democratic party and the policies of social liberalism (Dawson, 1994), are more likely to cue racialpolitical stereotypes toward political liberalism when compared to comparable white candidates. Latinos, who suffer from the same stereotypes as blacks (Bobo, 2001; Sigelman et al., 1995), will likely inspire a similar reaction. Racial-political stereotypes of Asians, on the other hand, are not rooted in the policies of social liberalism and minority driven policies (like affirmative action and welfare). I hypothesize that Asians will be the least racially polarizing candidates of all, and we will see weak to no racial effects in the results.

From this racial-hierarchy theory of race and candidate evaluation, I posit my second hypothesis:

- 2. Racial Hierarchy Hypothesis - Asians will be evaluated favorably when compared to blacks and Latinos. A racial hierarchy in candidate perception and the vote will emerge, with Asians on equal

\footnotetext{
${ }^{1}$ On the other hand, Asians are also seen as foreign and inscrutable. The "Model Minority" stereotype has been discussed at length by Lee (2000); Kim (1999); Wu (2003) among others. It is certainly possible that Asians will cue foreignness and that this could hurt the candidacies of Asian American candidates, however this is difficult to test, as there is no question on the CCES that relates to a candidate's foreignness. I plan to address these questions in future experimental studies that will test the effect of foreignness on vote choice and candidate perception.
} 
footing with whites, and blacks and Latinos below them.

\subsection{For Whom Does Race Matter?}

What segments of the population are most likely to oppose the political candidacies of minority groups? Kinder and Sanders (1996) argue that white antipathy toward minorities has been expressed as a subtle form of distrust of minority candidates and a hostility toward race policy. The existence of this distrust is rooted in the theory that while overtly prejudicial expressions are a thing of the past, a certain segment of the white population still very much holds "symbolically" racist views that penalize minorities under socially acceptable grounds (McConahay, 1986; Gaertner and Dovidio, 1986; Kinder and Sanders, 1996). Kinder and Sanders (1996) argue that these racial attitudes are stable and difficult to reverse. If this is true, then we should expect those with racially prejudicial attitudes to be inherently distrustful of minority candidates, and render harsher judgements upon minority candidates when compared to white candidates of the same partisan and ideological stripe. On the other hand, if the "egalitarian" narrative is a more accurate reflection of the world today, then we should see no significant differences between the evaluation of minority candidates and white candidates, when controlling for partisanship, spending, and ideology.

Most observational studies of race have examined the white electorate as a whole without examining

how different racial attitudes among whites may effect minority candidacies (Highton, 2004; Bullock, 1984). While recent studies have explored the influence of differing racial attitudes among whites on the evaluation of President Obama (Tesler and Sears, 2010; Jacobson, 2011; Kinder and Dale-Riddle, 2012), there has not yet been an observational study that examines the effect of racial attitudes on black, Latino, and Asian candidates at the congressional level. This paper examines the effect of differing racial attitudes on minority candidacies by utilizing data that contains survey questions meant to capture a respondent's racial attitudes.

From this respondent-contextual theory of race and candidate evaluation, I posit the third of three hypotheses:

- 3. Racial Resentment Hypothesis: Biased perceptions against minority candidates will be especially prevalent among the racially resentful segments of the electorate. 


\section{Data}

For this study, I use 2010 and 2012 Cooperative Congressional Elections Study (CCES) (Ansolabehere, 2010, 2012). The CCES is a nationally representative survey that has several important advantages over existing studies (Highton, 2004; Bullock, 2000). First, between the 2010 and 2012 CCES, there were roughly 100,000 respondents. This large sample means that there are enough respondents to examine every Congressional district in America, which allows for an all-encompassing examination of minority candidacies across the entire nation. Most critically, this data allows me to study candidates of every racial stripe, political orientation, and experience level. This survey data, in conjunction with the racial and political diversity of candidates who ran for Congress in 2010 and 2012, allows for a more rigorous exploration of the intersections of different candidate variables, such as race and incumbency, or candidate race and candidate evaluation. This variation in race, partisanship, and candidate type differs from previous studies, which only look at black candidates, who were mostly incumbent Democrats (Highton, 2004; Bullock, 2000).

\section{[Table 1 About Here]}

Table 1 shows the racial and political makeup for the candidates in 2010 and 2012 Congressional elections. $^{2} 135$ black candidates, 103 Latino candidates, and 37 Asian candidates ${ }^{3}$ ran for Congressional

\footnotetext{
${ }^{2}$ The racial makeup of the 2010 and 2012 Congressional Candidates were hand coded by the author as well as my colleague [redacted] from [redacted]. The rules for coding are laid out in the supplemental appendix, and candidate race was verified using the following racial and ethnic candidate lists: The Directory of Latino Elected Officials (http: / / www. naleo.org/directory.html, The African American Leadership Directory (http://aalfnw. org/portland/business-directory/). The racial makeup dataset for both these years can be found on my website [redacted].
}

${ }^{3}$ For the purposes of this study, South Asian candidates were coded as "Asian". 
office between the 2010 and 2012 elections. ${ }^{4}$ While most minority candidates ran as Democrats, there is a fair amount of political diversity among each of racial group. 28 black Republicans, 43 Latino Republicans and 8 Asian Republicans ran for Congress. On the other hand, there was substantially less political diversity among minority incumbents, almost all of whom were Democrats.

There is also substantial variation in the racial match-ups in these elections. A black candidate ran against a white candidate in 90 contests, a Latino candidate ran against a white candidate in 48 contests, and an Asian candidate ran against a white candidate in 27 contests. While there were races in which co-ethnics ran against one another, there was still a fair amount of diversity among the types of bi-racial elections. The racial and political diversity amongst candidates enables us to study how voters respond to different intersections of racial and political identities. For instance, we can observe whether voters view black, Latino, or Asian Republicans differently than black, Latino, or Asian Democrats.

Prior studies relied mostly on exit polling and aggregate vote data. The CCES is unique in several ways. The CCES asks its respondents to rate the ideology of their candidates on a 7-point scale. The 2010 CCES asks its respondents to rate the competence of their candidates on a 7-point scale (from very strong to very weak). The incorporation of ideology and competence ratings allows for a more nuanced and flexible measure of candidate evaluation that stands in contrast to the binary nature of the vote. Previous observational studies (Highton, 2004; Bullock, 2000) have looked exclusively at the vote, and while several important experimental studies (McDermott, 1998; Sigelman et al., 1995) have found that race can cue ideology, there has yet to be an observational study that looks at evaluations of candidates of different racial groups. With the CCES, we can look at factors other than the vote and examine how voters rate candidates of different races.

In addition to the CCES, I also incorporate new candidate ideal point estimations (called Campaign Finance Scores, or CFscores) pioneered by Bonica (2014) into my analysis. This allows us to do analysis on challengers in addition to incumbents. As previously shown in Table 1, minority candidates run for office but often lose, especially if they are Republicans. The use of CFscores allows me to incorporate

\footnotetext{
${ }^{4} \mathrm{~A}$ total of 1,740 candidates were possible if there was two party competition in every Congressional district. Between the two years, 78 contests did not feature opposition.
} 
a methodologically rigorous measure of challenger ideology into my analysis. These results provide an objective control for actual candidate ideology, which is important for any analysis of assessments of candidate ideology. Bonica's ideology estimates resemble DW-NOMINATE scores (Poole and Rosenthal, $1984 a, b)$ in that they map candidates onto a liberal-conservative dimension ranging from -3 (most liberal) to +3 (most conservative). In my study, CFScores serve as a proxy for a candidate's "true" ideology. 5

In order to examine the white vote, I excluded non-white respondents from the sample. I also excluded races that had no challenger.

\section{Results}

\subsection{Examining Racial Bias in Candidate Evaluation}

I start my analysis with the most basic and fundamental measure of racial bias: bias in the vote. If there is racial bias in the vote, then minority candidates should perform more poorly than their white counterparts. Table 2 shows the raw vote totals for all minority candidates vs. white candidates by party. At first glance, these results suggest that there exists a cumulative racial bias in the white vote against minority candidates of both parties. Compared to the baseline (white vs. white), black and Latino Democrats do marginally worse. Minority Republicans, on the other hand, do worse across the board, with Asian Republicans doing the worst of all. These results point to a persistent racial bias against minority candidates of almost all racial and political stripes, with the notable exception of Asians Democrats, who do better than the baseline. At the very least, this most basic examination of racial bias reveals that, despite a purported willingness to support minority candidates, whites are not voting for their minority candidates at the same rate as their white counterparts.

\section{[Table 2 About Here]}

At the same time, these results are very preliminary. They fail to control for central aspects of campaigns and candidate characteristics, such as incumbency, spending, and candidate ideology. It is possible

\footnotetext{
${ }^{5}$ The details of how Bonica generates his campaign finance scores is in Bonica (2014).
} 
these results are the result of electoral variables that are independent of race. For instance, many of the minority candidates who ran for office were challengers running against established incumbents. Perhaps minority candidates were unable to raise the same amounts of money to stay competitive with their white counterparts. It is also possible that minority candidates who ran were ideologically out of line with the electorates they were trying to represent.

In order to account for those electoral variables, I turn to a logit regression model that controls for non-racial electoral variables. The main dependent variable in the model is whether a respondent voted for the Democratic candidate, which is coded as " 1 " if the respondent voted for the Democrat and " 0 " if the respondent did not. The independent variable of interest is the race of the candidate, with a dummy variable being generated for each racial group and partisan status. If a candidate is a black Democrat, he or she is coded as a " 1 " under "Black Democrat." If a candidate is a black Republican, he or she is coded as a "1" under "Black Republican." The same coding scheme is done with Latino candidates and Asian candidates. White candidates are excluded, thus creating a baseline of two non-minority candidates. I split the model to look at Democratic and Republican candidates separately, with white candidate coparties as the baseline. Since the dependent variable is a vote for a Democratic candidate, if whites are discriminating against minority Democrats, we should see a significant and negative result on the coefficient for minority Democrat, whether they be black, Latino or Asian. This coefficient would be a comparison against white Democrats with similar candidate characteristics. If white respondents are discriminating against minority Republicans, we should observe a positive coefficient for the minority Republican.

I control for incumbency (along with open seats, with the excluded category being challengers), how much the candidate spent, how much the opposition spent, ${ }^{6}$ the candidate's Cfscore (meant to control for candidate ideology), and a control for the cycle year (a dummy variable for 2012). A regular set of

\footnotetext{
${ }^{6}$ I generated this measure of campaign spending by taking the total disbursements of all candidates and dividing it by two standard deviations to create a scale of -.5 to 7 with mean 0. See Gelman (2008) for more details.
} 
respondent level controls were also included into the model, including party identification (Democrat), ${ }^{7}$ respondent ideology (a 7-point ordered scale from "Very Liberal" to "Very Conservative"), education level (5-point ordered measure), respondent age, employment status (coded as "1" if the respondent was unemployed, "0" otherwise), and gender ("1" for female respondents). A random effects model with errors clustered at the district level was used in order to control for district level variance.

Table 3 shows the logit model on the vote with all the aforementioned controls. The first result worth noting is that black Democrats do significantly worse than whites. Latino Democrats also do significantly worse than whites. On the other hand, the results are insignificant for Asian Democrats. In order to illustrate these results in a more meaningful manner, I generated predicted probabilities by holding the other variables and varying candidate race. Black Democrats incur a $3.5 \%$ penalty in the vote when compared to whites. Latinos Democrats also incur a 5\% penalty in the vote when compared to whites. Republican blacks and Latinos, on the other hand, do not appear to suffer from the same biases that their Democratic counterparts do when all the controls are accounted for. The effect of race on minority Republicans is statistically insignificant across all racial groups. ${ }^{8}$ While the coefficient for Latino points in the positive direction (indicating bias against Latino Republicans), the strength of this coefficient is weak.

\section{[Table 3 About Here]}

Thus far, these results lend support to the racial-political stereotyping and racial hierarchy hypotheses. Minority Republicans do not incur a significant penalty among white voters when compared to white Republicans. Black and Latino Democrats, on the other hand, incur a significant racial penalty when

\footnotetext{
${ }^{7}$ Respondents who said they "leaned" towards the Democratic party were counted as partisans.
}

${ }^{8}$ Notably, the coefficient for Asian Republican is positive and large, indicating that respondents were more inclined to vote Democratic when an Asian Republican was running, although not significant. A difference test showed that Asian Republicans did do worse, however since scant few Asian Republicans sought office, it is difficult to draw any conclusions from this result. 
compared to their white counterparts. These results support the racial-stereotyping hypothesis. On the other hand, Asian Democrats perform significantly better than black or Latino Democrats among whites, which supports the racial hierarchy hypothesis.

The most important result is that, even after controlling for a host of electoral variables, there is still a bias against black and Latino candidates in the vote. These results stand in contrast with prior observational studies, and indicate certain minority candidates are indeed handicapped by their race. This is also evidence in support of the racial-political stereotype hypothesis and the racial hierarchy hypothesis. While this finding is notable in and of itself, the next step I take in this paper is to explore why we might be observing these biases in the vote.

\subsection{Partisanship and Racial-Political Stereotyping}

In order to explain racial bias in the vote, I posit two possible explanations. The first is that minorities are viewed as more ideologically extreme than their white counterparts. The second is that minorities are viewed as less competent than their white counterparts. Questions in the CCES allow us to explore how voters perceive their candidates in ways that could not be done before. In addition to the vote, we can also examine how voters see their candidates ideologically and assess candidate competence. Prior studies have established the importance of how voters perceive their candidates' ideological orientations and competence in determining vote choice (Hinich and Munger, 1994; Popkin, 1994; Vavreck, 2009; Jacobson and Kernell, 1983). Exploring how white voters might see their minority candidates as different in both these respects is critical in determining a possible intervening variable between race and vote choice. The dependent variable in the following analyses is how respondents rate the ideology and competence of his or her congressional candidate. Each respondent was asked to rate the candidates separately by party. For this reason, it was more methodologically convenient to divide the analysis in the following section by Democratic and Republican candidates.

First, I examine the ideological ratings of candidates. In order to generate a more meaningful measure of candidate ideology, I construct a measure of ideological difference by subtracting the ideological rating of the candidate from the ideological rating that the respondent gave themselves, which are both on a 7point scale. This generates a measure of ideological distance from the respondent, which is arguably 
more meaningful than a simple measure of ideology. By anchoring these ideological perceptions to self perceptions, this measure also corrects for scale heterogeneity, as respondents may have different meanings for what "liberal" means in Alabama as opposed to California. The variable produced is a 13-point ordered variable with 0 representing a respondent perceiving no ideological distance from that candidate. For example, if a candidate rates their own ideology as "Very Liberal" and rates their candidate as "Very Liberal," this would produce a 0 on this scale. Negative values mean that the respondent sees their candidate as ideologically to the left in relation to their own ideology, while positive values indicate an ideological placement of the candidate to the right.

Table 4 shows the result of a regression of ideological distance. The results of this regression paint a telling picture. Black and Latino Democrats are seen to be significantly further away ideologically from white respondents than white Democrats, even after accounting for a candidate's actual ideology (as measured by Cfscores). ${ }^{9}$ Asian Democrats, on the other hand, are not seen as ideologically distinct from white Democrats. Black, Asian and Latino Republicans are also not seen as significantly ideologically distinct from their white Republican counterparts.

\section{[Table 4 About Here]}

These results support both the racial-political stereotyping hypothesis and the racial hierarchy hypothesis. Black and Latino Democrats are seen as more ideologically liberal than whites, even when controlling for actual candidate ideology, and while Asian Democrats are also seen as more ideologically liberal than whites, the magnitude of this effect is significantly smaller when compared to Black and Latino candidates. The effect of race for minority Republicans, on the other hand, is insignificant across all racial groups. ${ }^{10}$ It also provides a possible explanation as to why we are seeing bias in the Democratic

\footnotetext{
${ }^{9}$ In order to vet the reliability of Cfscores as an ideological control, I split the sample and ran the model on incumbents using DW-NOMINATE as an ideological control, and yielded similar results. These results can be found in the appendix.
}

${ }^{10} \mathrm{~A}$ series of robustness tests were run on this data that verify this result, with some relatively minor variation. I ran the ordered regression using on the original candidate ideological rating, which can be 
vote against minorities. Whites see their black and Latino Democratic candidates as more ideologically misaligned with themselves, and this perceptual bias lead to a bias in the vote.

The other possibility is that whites are biased against minority candidates because they see minorities as less competent. In order to explore this aspect of candidate evaluation, I examine assessments of candidate competence. Respondents in the 2010 CCES were asked to rate the competence of their candidate on a 7-point scale, from "Very weak" to "Very Strong." Using a similar model that I used for both the vote and for ideology, I ran an ordered logit on ratings of competence on racial variables and other control variables. The 2012 CCES did not ask competence questions, so this analysis was run using only the 2010 CCES. The results of this ordered logit regression are presented in Table 5, which shows that black and Latino Democrats are seen as less competent when compared to white Democrats, even after controlling for incumbency, campaign spending, and candidate ideology. Asian Democrats, on the other hand, are seen ${ }^{11}$

\section{[Table 5 About Here]}

These results represent the first look at competence assessments of minority candidates. They suggest that perceptual biases against minority candidates remain pervasive even in the age of Obama and five decades after the Civil Rights Movement. Black and Latino Democrats suffer the most from these biases, but Latino Republicans are also seen as significantly less competent than their white counterparts. This result affirms the racial-political stereotyping hypothesis. The result for Asian Democrats, on the other hand, is not significant, which reaffirms the racial hierarchy hypothesis.

On the whole, the evidence suggests that white voters are perceptually biased against minority candidates, especially minority black and Latino Democrats. How do these candidate perceptions influence the racial vote? Accounting for these perceptions could account for the bias in the racial vote and paint found in the appendix. The cut point coefficients can also be found in the appendix.

${ }^{11}$ There was a lack of Asian Republicans in bi-racial contests in 2010, so I could not analyze the effect of competence on Asian Republicans. 
a clearer picture of what might cost minority candidates white votes. In order to explore this, I revisit the logit model for Democratic candidates from Table 3 and add ideological distance from respondent and competence assessments as control variables in the regression. The purpose of this regression is to examine the coefficients on race change in order to determine whether bias in ideological assessment or bias in competence assessment drives bias in the vote. Table 6 shows the results of the original logit on the vote in comparison to the same model with the ideological distance variable and competence variable added as controls. Because the competence question only appears in the 2010 CCES, I reproduce the original model on just the 2010 data. When controlling for competence assessments and ideological assessments, the results of the original regression change significantly. The coefficients on black and Latino Democrats become insignificant. This indicates that the bias that does exist against these minority candidates is captured mostly by ideological and competence assessments. ${ }^{12}$

[Table 6 About Here]

The results suggest that whites are voting against minority candidates because they view them as both less competent and more ideologically extreme. Blacks and Latinos continue to face deep-rooted perceptual biases that fit prevailing stereotypes and that directly effect their electoral prospects. These findings confirm arguments that minority candidates often win in spite of their race, and that racial bias is still prevalent in this "post-racial” era (Kinder and Dale-Riddle, 2012).

\subsection{Exploring Racial Bias in the Electorate}

The results so far point to a general bias against black and Latino Democrats. If there is indeed a racial bias against black and Latino Democrats, then the racial effect should be especially strong among those

\footnotetext{
${ }^{12}$ Because not every respondent answered the candidate evaluation question, the number of respondents drops between the original model and the control model. In order to ensure that these results were not the result of the loss of data, I ran both models on the subset of respondents that answered the candidate evaluation questions.
} 
with high degrees of racial resentment. Fortunately, the CCES asks two racial resentment questions that allow me to examine the effect of racial attitudes on minority candidate evaluations.

Respondents are asked the following: "The Irish, Italians, Jews and many other minorities overcame prejudice and worked their way up. Blacks should do the same without any special favors" and "Generations of slavery and discrimination have created conditions that make it difficult for Blacks to work their way out of the lower class." Respondents are asked how strongly they agree or disagree with these statements on a 5-point ordered scale. I combine the answers to both these questions to produce a 9-point measure of racial attitudes. I then interact the race of the candidate and the respondent's racial attitudes in the model, in order to examine how respondents rate their candidates based on their racial attitudes. ${ }^{13}$ The clearest way to test my hypothesis is to look at the marginal effects of the interaction. The marginal effects capture the difference in evaluation between the baseline group of white candidates (either Republican or Democrat), and the each racial group. I then plot the marginal effects of these interactions in order to visualize how the difference from the baseline changes as racial resentment increases.

[Figure 1 About Here]

Figure 1 shows the marginal effects of racial resentment on the probability that the respondent will vote for the Democratic candidate. The first row of Figure 1 shows the marginal effects for minority Democrats. The second row shows the marginal effects for minority Republicans. As racial resentment increases, white are significantly less likely to vote for black or Latino Democrats when compared to their white Democratic counterparts. The results are insignificant for Asian Democrats and minority Republicans of all racial groups. These results provide significant support for my hypotheses on racial hierarchy and candidate partisanship. Racial resentment works primarily against black and Latino Democrats.

\footnotetext{
${ }^{13}$ For the purposes of illustration, the interaction models used as a basis for the plots in this section are basic OLS models. The full regression model for each of these figures can be found in the supplementary appendix. I treat the racial resentment variable as continuous. Analysis done treating the racial resentment variable as ordered yields similar results. In addition, analysis using just one of the ordered measures also yields similar results to analysis using both scales.
} 
On the other hand, Asian Democrats and minority Republicans are spared overly negative evaluations from the racially resentful. Among those respondents with lower levels of racial resentment, minority Democrats appear to do better than white Democrats, although this result is not statistically significant. ${ }^{14}$

[Figure 2 About Here]

An examination of the marginal effects on competence evaluations shows similar results to the results in voting. Figure 2 show the marginal effects of racial attitudes for candidates of each racial group on competence. The most noticeable pattern among each of the racial groups is that negative racial attitudes are strongly related to lower competence ratings for black and Latino Democrats, but not for Asian Democrats and Black Republicans. ${ }^{15}$ Negative racial attitudes seem to have an effect on Latino Republicans, however the size of this effect is smaller in magnitude than it is for their Democratic counterparts. As racial attitudes become more positive, bias against minority candidates diminishes, especially at the lowest level of racial resentment. These results suggest that the bias in competence assessments in whites is driven by racial attitudes.

[Figure 3 About Here]

Does racial resentment similarly lead to a bias in ideological evaluation? Figure 3 shows the marginal effects of racial attitudes on ideology rating. Contrary to the results on competence assessments, white respondents with both positive and negative racial attitudes view black candidates as more liberal than their white counterparts. Notably, the magnitude of the racial effect for black candidates is much more pronounced for those with racially liberal attitudes, which suggests that black as an ideological cue

${ }^{14}$ This is in keeping with findings from Kinder and Dale-Riddle (2012) that racially liberal whites may be more favorable to minority candidates, however the relatively small proportion of respondents that scored low on the racial resentment scale likely led to increased uncertainty in the estimates.

${ }^{15}$ As noted previously, a lack of Asian Republicans meant I could not generate marginal effects for that class of candidate 
is especially strong among racial liberals. Only those with the most negative racial attitudes see Latino candidates as significantly more liberal than white candidates. The marginal effects are insignificant at all the other levels for Latinos. The marginal effects are insignificant across all levels for Asian candidates.

Not only do these results strongly support my third hypothesis, but they also point to an asymmetry in the way the racially resentful evaluate their minority candidates. The key takeaway from these findings is that there exists strong racial biases against minority candidates among the racially resentful, and that these biases are not centered around ideological evaluations, but rather assessments of competence and an ability to perform in office. This suggests that biases against minority candidates go beyond stereotypes about ideology, but are decidedly more insidious and discriminatory. While those with negative racial attitudes might distrust white Democrats because of ideology, they distrust minority Democrats because of a perceived lack of competence.

On the whole, the results of these interactions suggest that much of the bias in the vote against black and Latino Democrats comes from the racially resentful subsections of the population. Those who scored the highest on this scale represent a significant portion of the sample, easily a plurality (30\%). While the marginal effects were insignificant among respondents who are less racially resentful, those who scored in the first two quartiles of the racial resentment scale comprised of only $21 \%$ of the sample. ${ }^{16}$ This $^{2}$ proportional imbalance means the bias that afflicts minority Democrats is likely driven by the sheer number of those who hold negative racial attitudes.

\section{Discussion and Conclusion}

The results of this study show that despite the increasing representation of minority groups across racial stripes, minority candidates, especially Latino and black Democrats, still face significant hurdles, especially among those who hold strongly negative racial attitudes. Not only is this racial handicap significant, its effect is comparable to the marginal effect of variables like campaign spending and candidate ideology. The bias in the vote against minority candidates can be traced to perceptual biases in how whites

\footnotetext{
${ }^{16} \mathrm{~A}$ full table of summary statistics can be found in the appendix
} 
view their candidates' ideological leanings and competence. While prior research has shown that whites view black and Latino candidates as more liberal than their white counterparts, I find that whites also see black and Latino Democrats less competent, even after controlling for a candidate's actual ideology and for incumbency.

Race is an especially significant factor in the political calculus of racially resentful white Americans. Those who score highly on the racial resentment scale are significantly less likely to vote for Latino and black Democrats. On the other hand, white respondents with low levels of racial resentment are significantly more receptive to minority candidates. Yet because a plurality of whites hold moderately to very negative racial attitudes, these results point to a disturbing electoral reality for certain minority candidates: that there exists a persistent racial handicap for black and Latino Democrats. Kinder and Dale-Riddle (2012) found that racial resentment cost Barack Obama around 3\% of the white vote in the 2008 presidential election. This racial penalty not only applies to a national figure like President Obama, but also extends to black and Latino Congressional candidates as well. Whether this penalty is significant enough to swing individual elections, especially at the national level, is a separate question. Some studies have found that minority candidates are no more likely to lose than their white counterparts (Juenke and Shah, 2014), yet other studies have found that marginal differences and racially unequal turnout have a significant influence on who wins and loses elections, especially in bi-racial city and local elections (Hajnal, 2010). It seems that when minority candidates are successful it is often because they are able to overcome this handicap. As more and more minority candidates seek office in white plurality or majority districts, this racial handicap will undoubtedly become a more pressing issue for minority representation, especially since significant portions of the white electorate hold attitudes that are hostile towards minority candidacies.

Yet the results also shows that whether race is a significant impediment to minority candidacies depends primarily on three distinct contexts: the racial group to which the candidate belongs, the partisan identity of the candidate, and the racial attitudes of white respondents. Each of these contexts warrants its own separate discussion. When it comes to the candidacies of Asian candidates, it is telling that they are not afflicted by the same perceptual biases that afflict black and Latino candidates, which is in keeping with the racial-hierarchy hypotheses I laid out earlier in this paper. In addition, it seems as though Asian 
candidates do not suffer a penalty in the vote, or in competence and ideological assessments, despite prevailing stereotypes of perpetual foreignness. It is difficult to get at the possible effect of this stereotype because there is no clear way to measure how foreign a respondent perceives his or her candidate to be, nor is it clear what kind of effect this would have on the candidacies of Asian Americans. It is possible that the negative evaluations of Asian candidates among the racially resentful are the result of stereotypes of foreignness. An experimental design which tests the independent effect of having a foreign background would go a long way toward answering these questions.

White perception of minority Republicans has been an unexplored part of the literature, principally because comprehensive data on how whites view minority Republicans has not been available until recently. The results of this study show that whites view minority Republicans as categorically different than minority Democrats. While it might follow that the GOP label would correct for ideological bias against minority candidates, why we observe insignificant results on competence evaluations is less clear. That the Republican party label eliminates bias in both ideological and competence evaluations of minority candidates may speak to the strength of partisan labels that not only cue voters as to their politics, but also cue voters as to their racial nature. The Republican party label is so strong, it enables minority Republicans to make credible appeals to whites about their political ability and ideological leanings that minority Democrats cannot make.

To conclude, I return to the fundamental question in the study of race and ethnicity in American politics: does race matter? The answer to that question is yes, but with the caveat that is conditional on which racial group, what subsection of the population, and what type of candidate we choose to examine. It is clear from these results that race matters for minority candidates, who still face steep obstacles when it comes to appealing to white voters. In an increasingly diverse America, we must not only consider whether race biases whites against minorities, but also how different subsets of the population respond to different minorities. This study is merely an important first step in understanding how race matters in a modern era. But it is very clear that race does indeed still matter. 
Table 1: Racial Makeup for 2010 and 2012 Congressional Elections

\begin{tabular}{|l|l|l|l|}
\hline & Total & \% Republican & $\%$ Democrat \\
\hline Black & 135 & $20 \%$ & $80 \%$ \\
Latino & 103 & $41 \%$ & $59 \%$ \\
Asian & 37 & $21 \%$ & $79 \%$ \\
White & 1,387 & $56 \%$ & $44 \%$ \\
\hline & 1,662 & & \\
\hline
\end{tabular}

Table 2: Race of Candidate and Vote Choice in Contested Elections, 2010 and 2012

\begin{tabular}{|l|l|l|}
\hline Race Dem Candidate & \% Dem Vote & Diff. with baseline (white vs. white) \\
\hline White & 41 & \\
Black & 39 & $\mathbf{- 2 \%}$ \\
Latino & 37 & $\mathbf{- 4 \%}$ \\
Asian & 45 & $\mathbf{+ 4 \%} * *$ \\
\hline \hline Race Rep Candidate & $\%$ Rep Vote & Diff. with baseline (white vs. white) \\
\hline White & 55 & \\
Black & 50 & $\mathbf{- 5 \%}$ \\
Latino & 47 & $\mathbf{- 8 \%} * *$ \\
Asian & 35 & $\mathbf{- 2 0 \%} * *$ \\
*prob $<.05, * *$ prob $<.01$ &
\end{tabular}


Table 3: Logit Model of Democratic Vote on Race and Candidate Variables

\begin{tabular}{lcccc}
\hline \hline Variable & Democrats & (Std. Err.) & Republicans & (Std. Err.) \\
\hline \hline Candidate Race & & & & \\
\hline Black Candidate & $-0.199 *$ & $(.092)$ & -0.204 & $(.126)$ \\
Latino Candidate & $-0.272 *$ & $(.126)$ & 0.163 & $(.117)$ \\
Asian Candidate & 0.127 & $(.132)$ & 0.402 & $(.278)$ \\
\hline Candidate Characteristics & & & & \\
\hline Incumbent & $0.554 * *$ & $(.064)$ & $-0.542 * *$ & $(.062)$ \\
Open Seat & $0.156 *$ & $(.067)$ & $-0.340 * *$ & $(.067)$ \\
Democrat Spending & $0.280 * *$ & $(.051)$ & -0.025 & $(.045)$ \\
Republican Spending & -0.035 & $(.047)$ & $0.271 * *$ & $(.048)$ \\
Cycle (2012) & $0.700 * *$ & $(.041)$ & $0.595 * *$ & $(.041)$ \\
Democrat Cfscore & 0.116 & $(.060)$ & 0.074 & $(.057)$ \\
Republican Cfscore & $0.260 * *$ & $(.081)$ & $0.250 * *$ & $(.078)$ \\
\hline Respondent Characteristics & & & & \\
\hline Co-Partisan Respondent & $3.130 * *$ & $(.039)$ & $-3.004 * *$ & $(.040)$ \\
Respondent Ideology & $-0.688 * *$ & $(.012)$ & $-0.719 * *$ & $(.011)$ \\
Education & -0.016 & $(.011)$ & $0.031 * *$ & $(.011)$ \\
Age & 0.000 & $(.001)$ & $0.003 * *$ & $(.001)$ \\
Unemployed & -0.000 & $(.007)$ & -0.000 & $(.007)$ \\
Gender (female) & 0.009 & $(.034)$ & $0.117 * *$ & $(.033)$ \\
Constant & $0.563 * *$ & $(.167)$ & $3.273 * *$ & $(.149)$ \\
Random Effects Coef. & $0.383 * *$ & $(.026)$ & $0.391 * *$ & $(.026)$ \\
\hline \hline No of Obs & 45,174 & & 45,174 & \\
Log Likelihood & -12733 & & -13095 & \\
\hline$*$ prob $05 * *$ & & \\
\hline
\end{tabular}

$*$ prob $<.05, * *$ prob $<.01$; Standard errors in parentheses 
Table 4: Ordered Logit Model on Perception of Ideological Distance from Respondent

\begin{tabular}{lcccc}
\hline \hline Variable & Democrats & (Std. Err.) & Republicans & (Std. Err.) \\
\hline \hline Candidate Race & & & & \\
\hline Black Candidate & $-0.567 * *$ & $(.064)$ & 0.062 & $(.095)$ \\
Latino Candidate & $-0.516 * *$ & $(.077)$ & 0.012 & $(.091)$ \\
Asian Candidate & -0.171 & $(.091)$ & -0.013 & $(.188)$ \\
\hline Candidate Characteristics & & & & \\
\hline Incumbent & $-0.750 * *$ & $(.048)$ & $0.283 * *$ & $(.043)$ \\
Open Seat & -0.092 & $(.053)$ & -0.030 & $(.054)$ \\
Candidate Spending & $-0.253 * *$ & $(.040)$ & $0.152 *$ & $(.029)$ \\
Opposition Spending & $0.083 *$ & $(.037)$ & 0.033 & $(.038)$ \\
Cfscore & $0.734 * *$ & $(.048)$ & $0.729 * *$ & $(.054)$ \\
Cycle (2012) & $0.165 * *$ & $(.034)$ & $-0.163 * *$ & $(.031)$ \\
\hline Respondent Characteristics & & & & \\
\hline Co-Partisan Respondent & $0.813 * *$ & $(.055)$ & $0.205 * *$ & $(.050)$ \\
Respondent Ideology & $-1.436 * *$ & $(.019)$ & $-1.694 * *$ & $(.020)$ \\
Education & $-0.167 * *$ & $(.013)$ & $0.203 * *$ & $(.012)$ \\
Age & $-0.005 * *$ & $(.001)$ & $0.009 * *$ & $(.001)$ \\
Unemployed & 0.135 & $(.007)$ & 0.122 & $(.006)$ \\
Gender (female) & $0.255 * *$ & $(.031)$ & $-0.203 * *$ & $(.029)$ \\
Random Effects Coef. & $0.321 * *$ & $(.064)$ & $0.261 * *$ & $(.064)$ \\
\hline \hline No of Obs & 32,685 & & 38,144 & \\
Log Likelihood & -46173 & & -50489 & \\
\hline$* p r o b<.05, * * p r o b<.01$ & & &
\end{tabular}

$*$ prob $<.05, * *$ prob $<.01 ;$ Standard errors in parentheses 
Table 5: Ordered Logit Model on Competence Rating

\begin{tabular}{lcccc}
\hline \hline Variable & Democrats & (Std. Err.) & Republicans & (Std. Err.) \\
\hline \hline Candidate Race & & & & \\
\hline Black Candidate & $-0.596 * *$ & $(.101)$ & 0.315 & $(.175)$ \\
Latino Candidate & $-0.503 * *$ & $(.153)$ & -0.258 & $(.149)$ \\
Asian Candidate & -0.133 & $(.111)$ & & \\
\hline Candidate Characteristics & & & & \\
\hline Incumbent & $0.245 * *$ & $(.069)$ & $0.488 * *$ & $(.064)$ \\
Open Seat & 0.133 & $(.105)$ & 0.089 & $(.100)$ \\
Candidate Spending & -0.049 & $(.059)$ & -0.083 & $(.054)$ \\
Opposition Spending & -0.069 & $(.048)$ & -0.016 & $(.060)$ \\
Cfscore & $0.242 * *$ & $(.056)$ & -0.053 & $(.084)$ \\
\hline Respondent Characteristics & & & & \\
\hline Co-Partisan Respondent & $1.201 * *$ & $(.075)$ & $1.078 * *$ & $(.072)$ \\
Respondent Ideology & $-0.090 * *$ & $(.023)$ & $0.177 * *$ & $(.024)$ \\
Ideological Distance (Absolute Value) & $-0.567 * *$ & $(.018)$ & $-0.588 * *$ & $(.021)$ \\
Education & $0.097 * *$ & $(.018)$ & $0.048 * *$ & $(.017)$ \\
Age & 0.002 & $(.001)$ & $-0.003 *$ & $(.001)$ \\
Unemployed & $-0.249 * *$ & $(.095)$ & -0.073 & $(.098)$ \\
Gender (female) & 0.037 & $(.042)$ & $0.151 * *$ & $(.041)$ \\
Random Effects Coef. & $0.250 * *$ & $(.027)$ & $0.261 * *$ & $(.034)$ \\
\hline \hline No of Obs & 16,014 & & 18,321 & \\
Log Likelihood & -20780 & & -22059 & \\
\hline$*$ prob $<.05, *$ prob $<.01 ;$ Standard & & &
\end{tabular}

$*$ prob $<.05, * *$ prob $<.01 ;$ Standard errors in parentheses 
Table 6: Comparison of Logit Model of Democratic Vote on Race with Ideology and Competence Controls (2010)

\begin{tabular}{lclcr}
\hline \hline Variable & Original & (Std. Err.) & Control & (Std. Err.) \\
\hline \hline Candidate Race & & & & \\
\hline Black Democrat & $-0.492 * *$ & $(.194)$ & 0.364 & $(.270)$ \\
Latino Democrat & $-0.677 * *$ & $(.256)$ & -0.382 & $(.341)$ \\
Asian Democrat & 0.002 & $(.246)$ & 0.063 & $(.340)$ \\
\hline Candidate Characteristics & & & & \\
\hline Incumbent & $0.515 * *$ & $(.115)$ & $0.399 *$ & $(.154)$ \\
Open Seat & -0.042 & $(.162)$ & 0.111 & $(.232)$ \\
Democrat Spending & $0.190 *$ & $(.095)$ & 0.102 & $(.127)$ \\
Republican Spending & -0.056 & $(.070)$ & 0.006 & $(.096)$ \\
Democrat Cfscore & $0.220 *$ & $(.093)$ & $-0.229 *$ & $(.118)$ \\
Republican Cfscore & $0.322 *$ & $(.142)$ & $0.386 *$ & $(.186)$ \\
\hline Respondent Characteristics & & & & \\
\hline Democratic Party ID & $3.158 * *$ & $(.063)$ & $2.455 * *$ & $(.101)$ \\
Respondent Ideology & $-0.675 * *$ & $(.019)$ & $-0.517 * *$ & $(.032)$ \\
Education & $0.057 *$ & $(.023)$ & -0.051 & $(.036)$ \\
Age & 0.005 & $(.002)$ & 0.006 & $(.003)$ \\
Unemployed & 0.006 & $(.012)$ & -0.000 & $(.018)$ \\
Gender (female) & -0.055 & $(.057)$ & -0.139 & $(.087)$ \\
Ideological Distance (Democrat) & & & $-0.583 * *$ & $(.031)$ \\
Competence Rating (Democrat) & & & $0.971 * *$ & $(.034)$ \\
Constant & -0.290 & $(.0266)$ & $4.429 * *$ & $(.394)$ \\
\hline \hline No of Obs & 17,731 & & 12,530 & \\
Log Likelihood & -4788 & & -1997 & \\
\hline *prob $<.05, * *$ prob $<.01 ;$ Standard errors in parentheses & & \\
& & & &
\end{tabular}



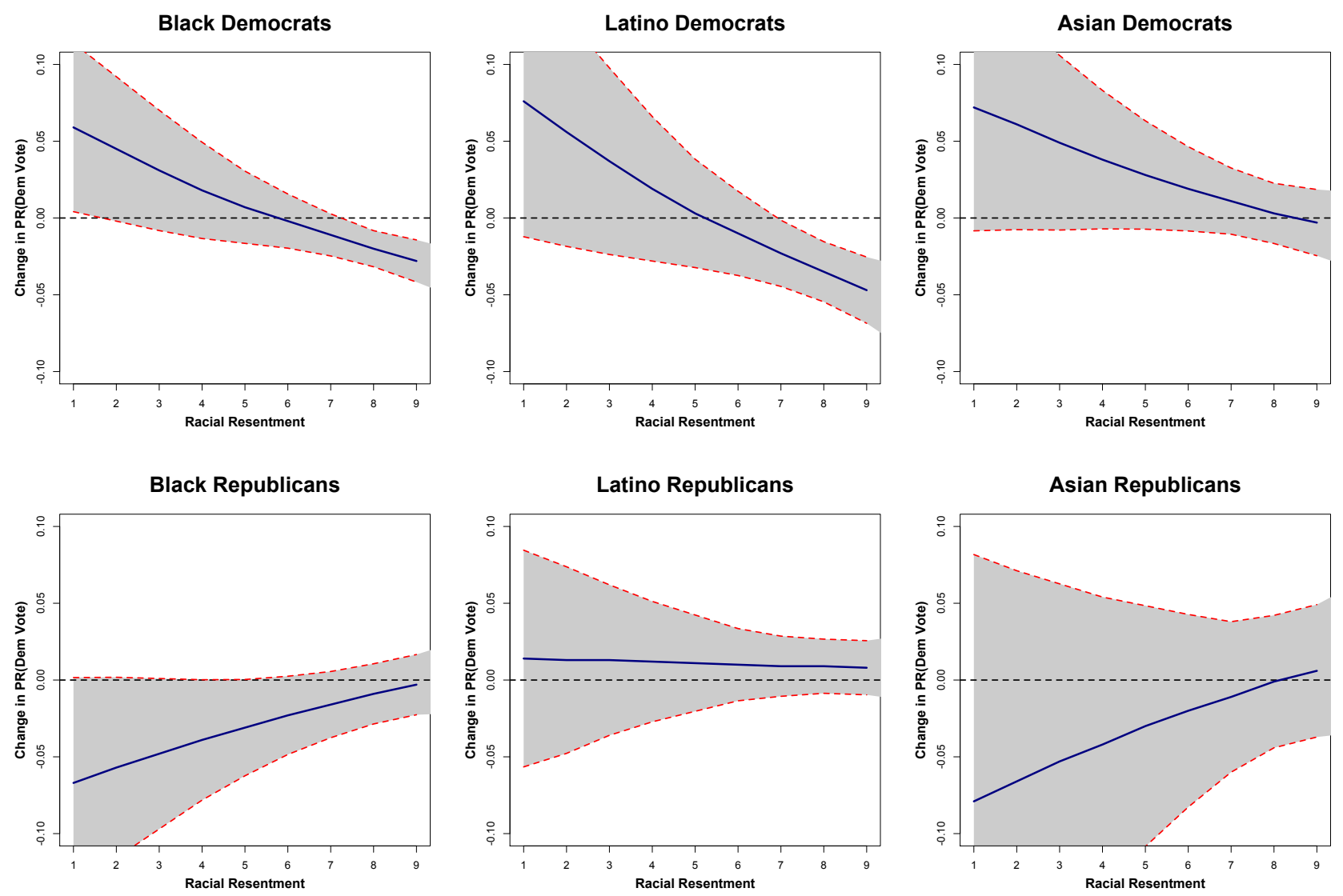

Figure 1: Marginal Effects of Racial Resentment on Vote 

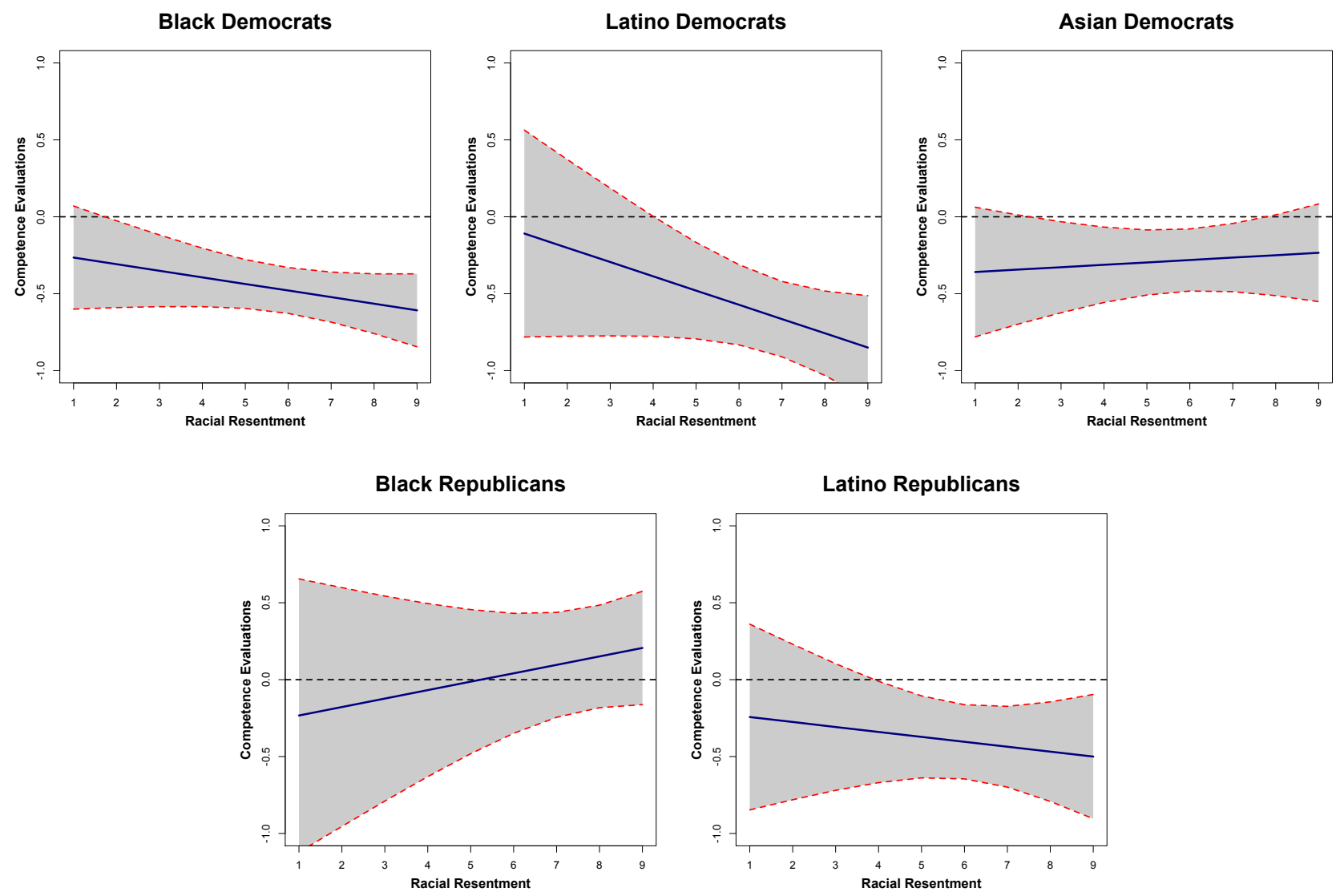

Figure 2: Marginal Effects of Respondent Racial Attitudes on Competence Evaluations 


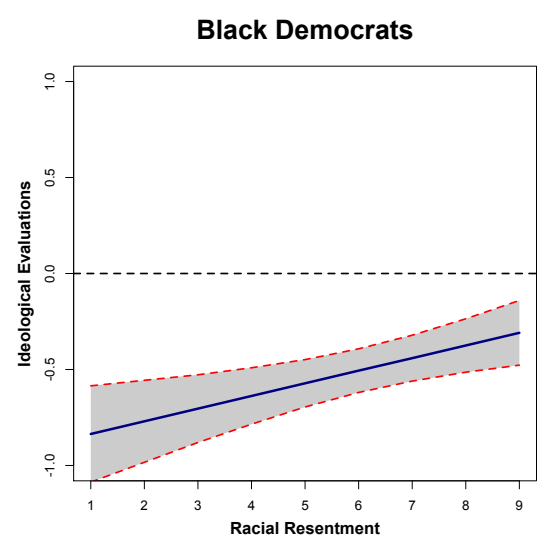

Black Republicans

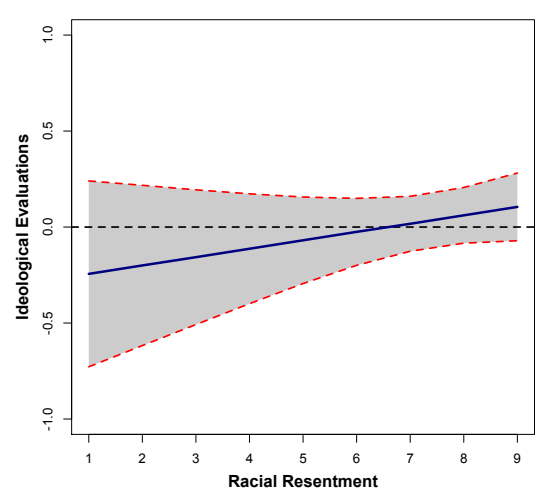

Latino Democrats

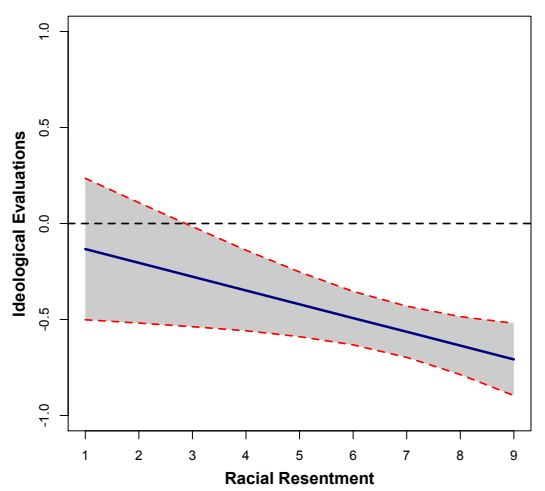

Latino Republicans

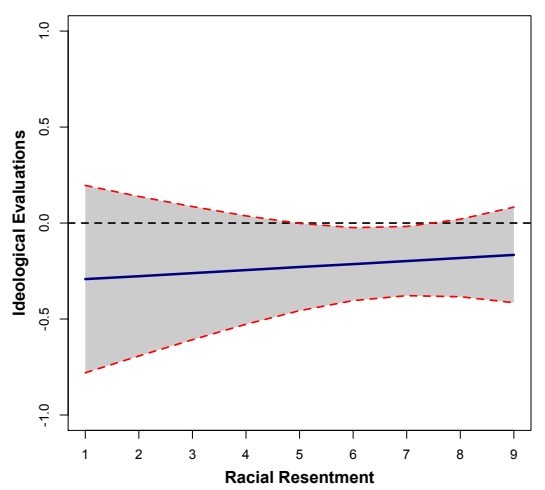

Asian Democrats

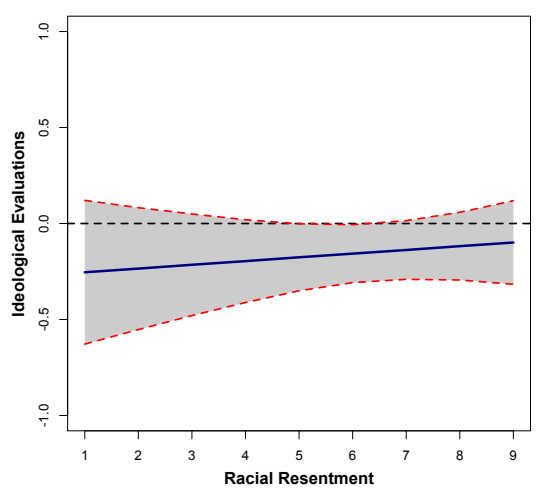

Asian Republicans

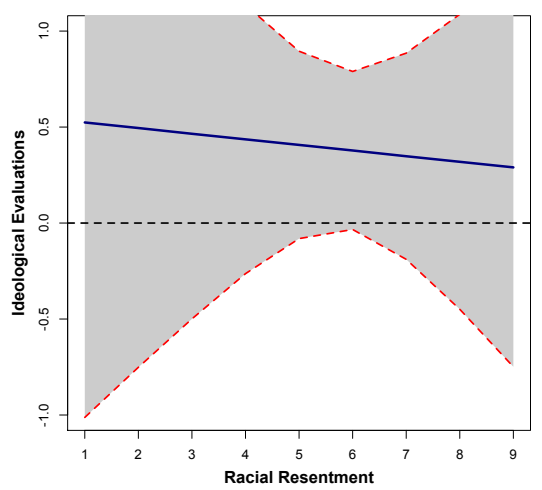

Figure 3: Marginal Effects of Respondent Racial Attitudes on Ideological Evaluations 


\section{References}

Abrajano, Marisa A. and Michael Alvarez. 2010. New Faces, New Voices: The Hispanic Electorate in America. Princeton University Press.

Abramowitz, Alan I. 1994. "Issue Evolution Reconsidered: Racial Attitudes and Partisanship in the US Electorate." American Journal of Political Science (38):1-24.

Ansolabehere, Stephen. 2010. "Cooperative Congressional Election Study 2010: Common Content. Computer File, Release 4.” Cambridge, MA: Harvard University.

Ansolabehere, Stephen. 2012. "Cooperative Congressional Election Study 2012: Common Content. Computer File, Release 1.” Cambridge, MA: Harvard University.

Baretto, Matt. 2007. "Sí Se Puede! Latino Candidates and the Mobilization of Latino Voters.” American Political Science Review (101):425-441.

Beck, Michael Lewis, Charles Tien and Richard Nadeau. 2010. “Obama’s Missed Landslide: A Racial Cost?" PS: Political Science and Politics 43(1):69-76.

Bobo, Lawrence. 2001. Racial Attitudes and Relations at the Close of the Twentieth Century. In America Becoming: Racial Trends and Their Consequences, ed. Neil Smelser, William Julius Wilson and Faith Mitchell. Vol. 1 National Academies Press.

Bonica, Adam. 2014. "Ideology and Interests in the Political Marketplace.” American Journal of Political Science 57:294-311.

Bullock, Charles S. 1984. "Racial Crossover Voting and the Election of Black Officials." Journal of Politics 46(1):238-251.

Bullock, Charles S. 2000. Partisan Changes In the Southern Congressional Delegation and the Consequences. In Continunity and Change in House Elections, ed. Morris Fiorina David W. Brady, John F. Cogan. Standford, CA: Stanford University Press. 
Bullock, Charles S. and Richard E. Dunn. 1999. "The Demise of Racial Districting and the Future of Black Representaiton.” Emory Law Journal 48:1209-1253.

Citrin, Jack, Donald Philip Green and David O. Sears. 1990. "White Reactions to Black Candidates: When Does Race Matter?” Public Opinion Quarterly 54:79-96.

Dawson, Michael C. 1994. Behind the Mule:Race and Class in African-American Politics. Princeton University Press.

Feldman, Stanley and Leonie Huddy. 2005. "Racial Resentment and White Opposition to RaceConscious Programs: Principles or Prejudice?” American Journal of Political Science 49(1):168-183.

Gaertner, Samuel L. and John F. Dovidio. 1986. The Aversive Form of Racism. In Prejudice, Discrimination, and Racism, ed. Samuel L. Gaertner and John F. Dovidio. Orlando:Academic Press.

Gelman, Andrew. 2008. “Scaling Regression Inputs by Dividing by Two Standard Deviations.” Statistics in Medicine 27:2865-2873.

Hajnal, Zoltan L. 2001. "White Residents, Black Incumbents, and a Declining Racial Divide.” American Political Science Review 95:603-617.

Hajnal, Zoltan L. 2007. Changing White Attitudes Toward Black Political Leadership. Cambridge University Press.

Hajnal, Zoltan L. 2010. America’s Uneven Democracy. Cambridge University Press.

Hajnal, Zoltan L. and Taeku Lee. 2011. Why Americans Don't Join the Party: Race, Immigration, and the Failure of Political Parties to Engage the Public. Princeton University Press.

Highton, Benjamin. 2004. "White Voters and African American Candidates for Congress." Political Behavior 26(1):1-25.

Highton, Benjamin. 2011. "Prejudice Rivals Partisanship and Ideology When Explaining the 2008 Presidential Vote across the States." PS: Political Science and Politics 44(3):530-535. 
Hinich, Melvin J. and Michael C. Munger. 1994. Ideology and the Theory of Political Choice. Ann Arbor, MI: University of Michigan PRess.

Jacobsmeier, Matthew L. 2014. "Racial Stereotypes and Perceptions of Representatives' Ideologies in U.S. House Elections.” Legislative Studies Quarterly 39(2):261-291.

Jacobson, Gary C. 2011. Public Opinion and the Presidency: The Obama and Anti-Obama Coalitions. In The Obama Presidency: Appraisals and Prospects. CQ Press College.

Jacobson, Gary C. and Samuel Kernell. 1983. Strategy and Choice in Congressional Elections. Yale University Press.

Jones, Jeffrey M. 2012. “Atheists, Muslims See Most Bias as Presidential Candidates.”.

URL: http://www.gallup.com/poll/155285/atheists-muslims-bias-presidential-candidates.aspx

Juenke, Eric Gonzalez and Paru Shah. 2014. "Race, Partisanship, and Minority Representation in the States.” Presented at the 2014 Western Political Science Association Conference.

Kim, Claire Jean. 1999. “The Racial Triangulation of Asian Americans.” Politics Society 27(107):105138.

Kinder, Donald R. and Allison Dale-Riddle. 2012. The End of Race? Obama, 2008, and Racial Politics in America. Yale University Press.

Kinder, Donald R. and Lynn M. Sanders. 1996. Divided by Color: Racial Politics and Democratic Ideals. University Of Chicago Press.

Lee, Taeku. 2000. Racial Attitudes and the Color Line(s) at the Close of the Twentieth Century. In The State of Asian Pacific America: Transforming Race Relations, ed. Paul M. Ong. Los Angeles: LEAP/UCLA Asian Pacific American Public Policy Institute.

Locksley, Anne, Ernest Borgida, Nancy Brekke and Christine Hepburn. 1980. "Sex Stereotypes and Social Judgement." Journal of Personality and Social Psychology (39):821-31.

Masuoka, Natalie. 2006. "Together They Become One: Examining the Predictors of Panethnic Group Conciousness among Asian Americans and Latinos.” Social Science Quarterly 87(5). 
McConahay, John B. 1986. Modern Racism, Ambivalence, and the Modern Racism Scale. In Prejudice, Discrimination, and Racism, ed. John F. Dovidio and Samuel L. Gaertner. Orlando:Academic Press.

McDermott, Monika. 1998. "Race and Gender Cues in Low-Information Elections.” Political Research Quarterly 51(4):895-918.

Nicholson, Stephen P. 2011. “Polarizing Cues.” American Journal of Political Science 56(1):52-66.

Piston, Spencer. 2010. "How Explicit Racial Prejudice Hurt Obama in the 2008 Election." Political Behavior 32(4):431-51.

Poole, Keith T. and Howard Rosenthal. 1984a. "The Polarization of American Politics.” Journal of Politics 46(4):1061-1079.

Poole, Keith T. and Howard Rosenthal. 1984b. "U.S. Presidential Elections 1968-80: A Spatial Analysis." American Journal of Political Science .

Popkin, Samuel L. 1994. The Reasoning Voter: Communication and Persuasion in Presidential Campaigns. Chicago: University of Chicago Press.

Rahn, Wendy M. 1993. "The Role of Partisan Stereotypes in Information Processing about Political Candidates.” American Journal of Political Science 37(2):472-496.

Reeves, Keith. 1997. Voting Hopes or Fears? White Voters, Black Candidates and Racial Politics in America. New York: Oxford University Press.

Schaffner, Brian F. 2011. "Racial Salience and the Obama Vote.” Political Psychology 32(6):963-88.

Schuman, Howard, Charlotte Steeh and Lawrence Bobo. 1985. Racial Attitudes in America. Harvard University Press.

Sigelman, Carol K., Lee Sigelman, Barbara J. Walkosz and Michael Nitz. 1995. "Black Candidates, White Voters: Understanding Racial Bias in Political Perceptions." American Journal of Political Science 39(1):243-265.

Sniderman, Paul M. and Edward G. Carmines. 1999. Reaching Beyond Race. Harvard University Press. 
Stephens-Davidowitz, Seth. 2013. "The Cost of Racial Animus on a Black Candidate: Evidence Using Google Data.” Working Paper.

Terkildsen, Nayda. 1993. "When White Voters Evaluate Black Candidates: The Processing Implications of Candidate Skin Color, Prejudice, and Self-Monitoring." American Journal of Political Science 37(4):1032-1053.

Tesler, Michael and David O. Sears. 2010. Obama's Race: The 2008 Election and the Dream of a Post-Racial America. University Of Chicago Press.

Thernstrom, Abigail and Stephan Thernstrom. 1999. America in Black and White: One Nation, Indivisible. Simon Schuster.

Vavreck, Lynn. 2009. The Message Matters: The Economy and Presidential Campaigns. Princeton, NJ: Princeton University Press.

Voss, D. Stephen and David Lublin. 2001. "Black Incumbents, White Districts: An Appraisal of the 1996 Congressional Elections.” American Politics Reseach 29(2):141-182.

Williams, Linda F. 1990. White/Black Perceptions of the Electability of Black Political Candidates. In Black Electoral Politics, ed. Lucia J. Barker. New Brunswick, NJ: Transaction.

Wu, Frank. 2003. Yellow: Race in America Beyond Black and White. Basic Books. 